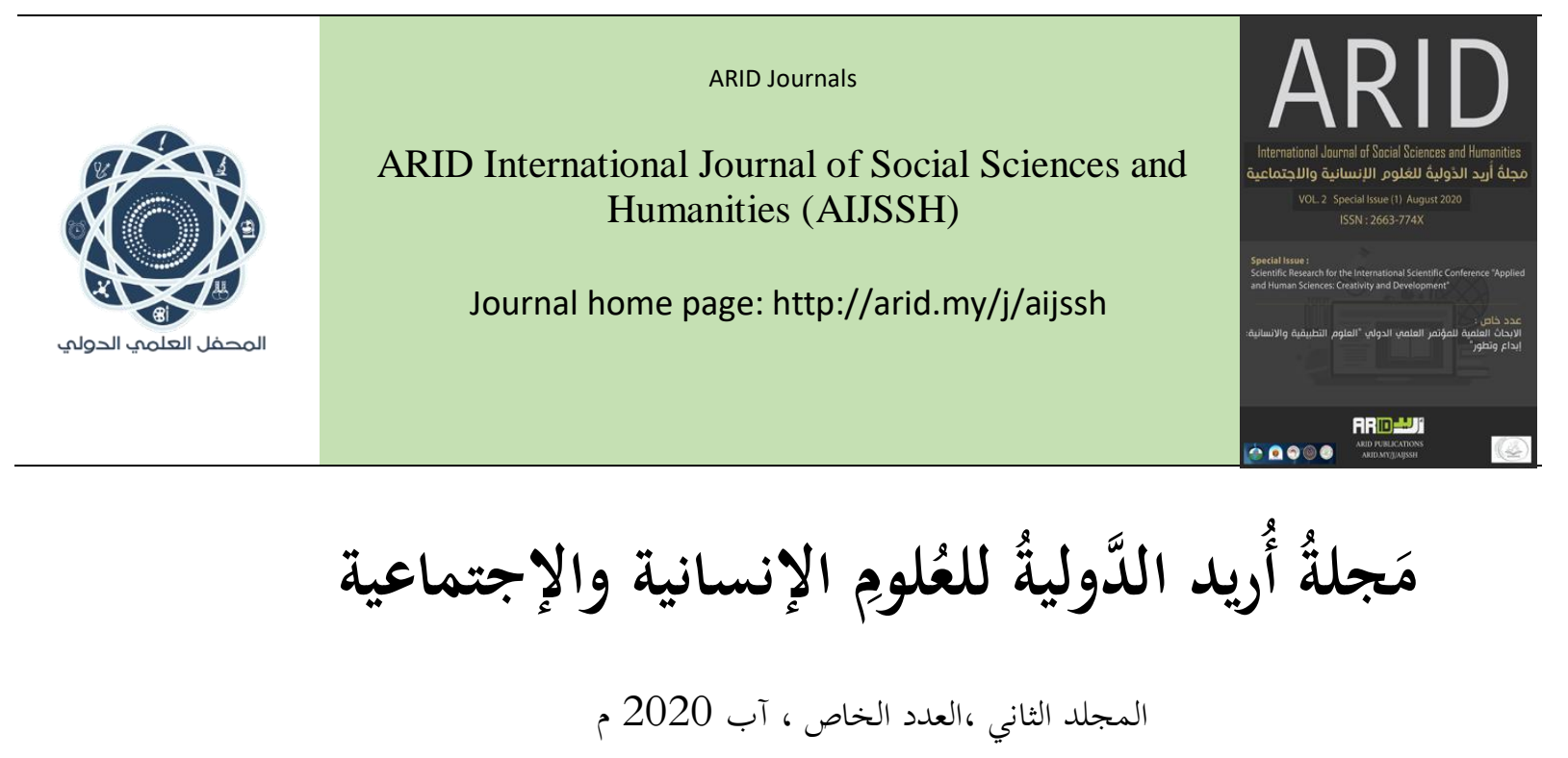

\title{
E-marketing through Social Media Platforms under the Umbrella of Persuasive Language: Explanatory Study for some Private Companies Using Social Media Platforms
}

Haider Fadhel Kadhem*,

Nisreen Jasim Mohammed, Zayad Ali Abbas

Department of Public Administration- College of Economics and Administration- University of Baghdad- Iraq

\footnotetext{
التسويق الإلكتروني عبر منصات التواصل الاجتماعي في ظل اللغة الإقناعية:

دراسة إستطلاعية لآر اءء عينة من الثركات الأهلية المستخدمة لشبكات التواصل الإجتماعي زياد علي عباس نسرين جاسم محمد * حيدر فاضل كاظم قسم الإدارة العامة ـ كلية الإدارة و الاقتصاد -جامعة بغداد ــ العراق

hader@uobaghdad.edu.iq arid.my/0004-7438

https://doi.org/10.36772/arid.aijssh.2020.s.219
} 


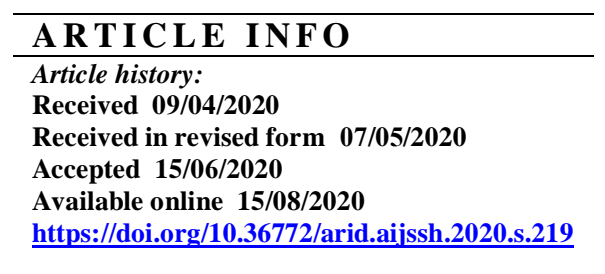

\begin{abstract}
E-marketing means simply buying and selling through the internet. It consists of two important components, online shopping and online purchasing. The two components of emarketing play a vital role to attract customer's attention as well as interact with them through the product information details and characteristics. Social media platforms like Twitter, Facebook, Instagram, and others social media platforms can be one of the most obvious advantages of e-marketing due to the fact that they become a dynamic engine not only promote local businesses, but also help international businesses grow. Businesses have utilized social media platforms to distribute their goods quickly and widely. Persuasive language through social media platforms considers a critical advantage with great attention to argument quality, post popularity, and post attractiveness. The problem of the study relies on neglecting some companies the significance of using persuasive language to advertise their goods and services. The importance of the research focuses on the rule of persuasive language in growing, prospering, and attracting more customers. Research sample consisted of 132 small companies in Iraq that use social media platforms effectively in order to attract customers to their goods and services. The results were analyzed by using SPSS and AMOS programs. The results of the research shows that persuasive language can support small business by taking advantage of utilizing social media platforms in order to attain a high niche and compete with other companies in the marketplace. Therefore, public sector institutions and companies must take into consideration the private sector's experience in how to deal with customers or beneficiaries and gain profitable benefits and returns at the same time.
\end{abstract}

Keywords: E-marketing; Social media platforms; Small companies; persuasive language. 


\section{الملخص}

التسويق الإلكتروني يعني ببساطة إجراء عمليات البيع والثراء عبر الإنترنت. التسويق الإلكتروني يتضمن مكونين مهمين،

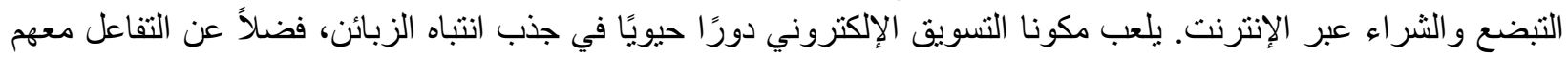

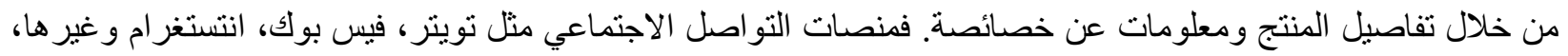

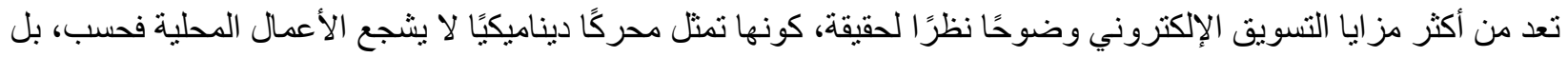

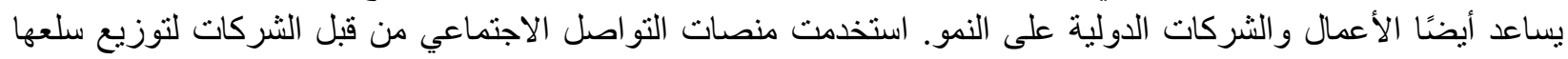

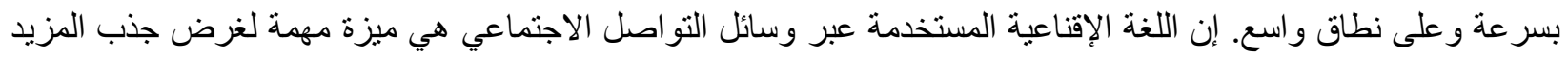

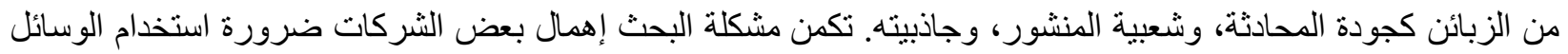

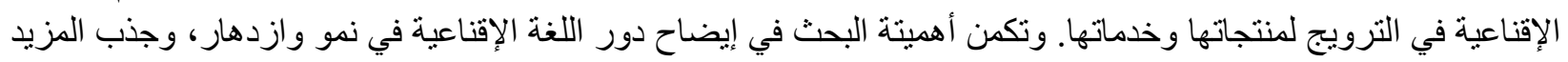

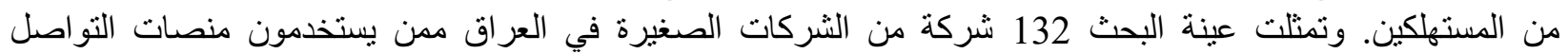

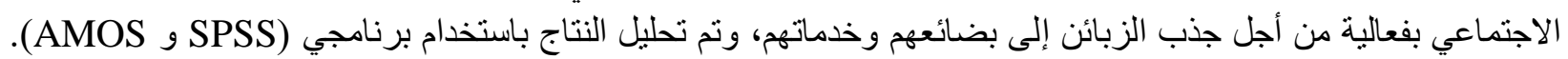

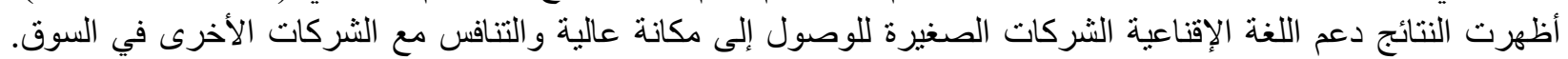
لذللك يتعين على مؤسسات شركات القطاع العام الاستفادة من خبرة القطاع الخاص في كيفية التعامل مع الزبائن أو التهات المستفيدين

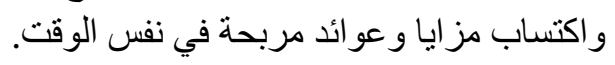

الكلمات المفتاحية: التسويق الإلكتروني، منصات التو اصل الاجتماعي، الثركات الصغيرة، اللغة الإقناعية. 


\section{Introduction}

Companies in the $21^{\text {st }}$ century attempt to reduce costs and respond quickly to market needs. Traditional marketing consumes the company's money and employee's efforts when no professionals of business man enroll in its process and implementation. E-marketing involves all commercial transactions such as selling, purchasing, exchanging, marketing, etc. that function electronically. It plays a vital role in facilitating all commercial transactions with rapid spread and unlimited space.

Rosen states that e-marketing "covers the range of online business activities for products and services, both business-to-business and business-to-consumers, through the Internet" [11, 4]. We can understand from the definition above not only e-marketing through social media platforms means using the internet for selling and buying goods, but it also describes the nature of the interaction process between companies and customers. Rosen (2002) mentioned that e-marketing contains two main aspects. First of all, online shopping that involves the range of actions and information that helps customers who want to reach an informed buying decision and choice, by giving them the essential and indispensable information to establish and manage business with companies. Second, online purchasing which refers to technological means, used by the companies to interact with customers electronically through exchanging information and merchandise buying details $[11,4]$.

The persuasive language uses social media platforms like Twitter, Facebook, Instagram, and others social media platforms for e-marketing, to create obvious advantages through the quality of argument, post popularity, and post attractiveness. The structural framework of this paper contains two main variables; persuasive language and its role in enhancing companies' performance on using social media platforms for e-marketing by means of argument quality, post popularity, and post attractiveness. 


\section{Literature Review}

The interactive atmosphere of companies and costumers through social media platforms becomes a dynamic engine to promote e-marketing. With high-speed growth technologies, social media platforms have been known one of the significant tools of e-marketing. They lead businesses to be successful. A persuasive language through Social media platforms has become a fundamental channel in business strategies. For instance, Mr. Kimball stated, "I would love to say that I just had a really good idea and strategy, but Twitter has been pretty essential to my success". [8]

Companies that want to achieve their goals and get people's attention toward their merchandise discover that through social media platforms, their manual work can be done effectively and quickly. Thoring (2011) declared that in the last five years until now, millions of individuals are still increasing their engagement in social media, which can be an advantage or a disadvantage for businesses utilizing e-marketing. From one standpoint, social media has the biggest community that can easily access. On the contrary, the manipulation of data and brand pictures on social media platforms have become controlled by the customers rather than companies. [13] Social Media platforms can be an effective tool for e-marketing through various reasons such as low-cost advertisements, open and unlimited space, interactive cooperation between company and its customers, honest commitment to build a comprehensive atmosphere that provide a selfcontrol to customers, and valid source of further new business opportunities. [3]

A convincing language through social media platforms uses to create argument quality, post popularity, and post attractiveness by informing and making a company's customers up-to-date events, products, and other announcements. Miller clarified that not only social media platforms nowadays enhance business to earn more and more money, but also teach business how they could assembly with their customers through interactive relationship. Small companies can take advantage of utilizing social media platforms to communicate immediately with customers by 
asking someone else to do their business [8]. Banerji who conducts commercial products at Twitter, said "We're finding the emotional distance between businesses and their customers is shortening quite a bit". [8]

\subsection{Persuasive language}

Persuasive language simply means convincing customers to understand daily issues that face companies' customers and address them properly. Persuasive language creates an environment where both companies and their customers interact with each other, through taking into consideration costumer's needs, sending and receiving feedback about new products or obstacles that need to be modified. For example, Dane, who works for Nike and represents it, uses Twitter to interact with Nike's followers. He mentioned that he had to find his "Nike voice" (S. Dane, personal communication, 2013). He spoke about his understanding and communication with Nike's customers. Dane also commented that one representative worked for another company tweeted inappropriate comments and that person got fired because of his inappropriate words to followers. Dan essentially indicted that social media platforms are known as the most interactive e-marketing. Customers who want to complain should be specific and brief to expose their problems. In contrast, people who are responsible for answering questions should be conversational and find a persuasive language that is suitable with their company's aims or goals (S. Dane, personal communication, 2013).

Many companies regard persuasive language as a dynamic approach to reach customers and get involved with them. Social media platforms retain an appropriate e-marketing connection. Firms enhance their persuasive language techniques through keeping close connections and interactions with shoppers by considering social media platforms as a supplemental way to communicate with customers. In addition, in the end of 2010, more than a half percent of "fortune 500 firms" have had a Twitter account "up from 35 percent the previous year" [2], contrasted to almost sixty percent of firms that have had a Facebook account at the same period of time. [2] 
Firms consider the persuasive language as a customer service desk through utilizing social media platforms for marketing. For example, Whole Foods, the biggest retailers on Twitter, has around 1.7 million followers. Erwin is one of the Whole Foods employees who monitors the account of Whole Foods on Twitter. Erwin also esteems follower's inquiries produce three-quadrates of Whole Food traffic. Erwin mentioned that social media platforms are not about one's self, but it is about how to get audience to be involved and avoid being bored. [10]

Therefore, companies are spreading out their persuasive messages as much as they did previously take part in social media effectively through combining content, paying attention to societies, starting relationships, developing cooperation, and sharing customer's opinions. [13]

\subsubsection{Argument Quality}

Argument quality refers to how the posts of the company could carry a convincing influence on customers. [7] Hence, companies ought to set a list of standards which allow them to evaluate the quality of social-media-based conversations. Companies can make its customers feel special by providing exceptional deals, information, treating, and offers. Furthermore, customers would feel kind of exclusivity in comparison to customers of other companies. [4]

\subsubsection{Post Popularity}

Post popularity of persuasive language represents the ability of the company to track its posts and respond customer's comments and complaints in a manner and proper way. [7] Guffey and Loewy (2013), found that airlines companies such as Delta, JetBlue, and United Airlines are using a persuasive language through social media platforms to notify their customers about new data, declare discounting offers and others. For example, when an inquiry or complaint contains private information or is not an ordinary request, the agent will submit that question to a direct message for processing the question away from the public's eyes. That will keep customer's 
personal information from any inappropriate problem or mistake that could hurt the company's customers. [5]

\subsubsection{Post Attractiveness:}

Post attractiveness means characteristics of the company's post that distinguish among others [7] Weber (2009), commented that firms attract individuals for their goods by recognition, high sales, and awareness of firm's services and products [14,11-12]. According to Bourne, companies can attract and get connected with people who want to be hired through posting an announcement about needing a part-time assistant. After several minutes, companies receive faster responses and have dozen inquiries. With a couple of days, the number may increase dramatically. That will generate great interaction by sending and receiving responses or feedback. [1]

\section{2. .E-marketing through Social Media Platforms}

Social media platforms enable companies to reach customers through posting their favorite merchandise and service using new ways of shopping to attract diverse and wide range of customers. Companies concern about costumers' opinion with regards to the quality of their products and services. Therefore, the outstanding numbers of costumers the company approaches reflect prominent performance and high target markets. [9]

Social media platforms assist business in many ways to reach a solid reputation. They have become widespread e-marketing for three reasons: unlimited space, faster response, and profitable business. Companies can pay much less than television advertisements or sometimes can be free. For example, some social media platforms like Twitter started a partnership with American Express cardholders and provided a unique reduction in cost and low price throughout specific hash tags. Followers who want to participate as American Express cardholders should first identify their 
American Express cards before registering in the system. Afterward, they will get discount when they want to advertise. Therefore, small businesses can take advantage through extending their businesses in social media platforms to reach as many people as possible through those discounting advertisements. [6]

\section{Methodology and major findings:}

\subsubsection{Research Methodology}

The authors used descriptive analysis to conduct this research. Data were collected test questions of 132 private companies in Iraq randomly by using a 5 Likert scale questionnaires. These companies were selected to find out how persuasive language utilizes social media platforms for marketing effectively.

As seen in Table (1), the sample study reached an increase with $66 \%$ of female participants in comparison of males, 34\%. Both categories who have maintained their academic attainment with no less than a high school degree, which indicates the ability of the examined sample to understand the variables of the research and its items, and to respond to their contents properly. As with the bachelor's degree, it initially reached $52 \%$ in comparison with $37 \%$ of high school degree, $7 \%$ of master's degree, and $4 \%$ of $\mathrm{PhD}$ degree respectively.

As for the ages of the research sample, it was distributed according to the result percentages. The age group between (28-32) years has the majority percentage by $33 \%$ followed by $28 \%$ of (1822 ) years in contrast with $17 \%$ of (23-27) years and $10 \%(33-37)$ years, $7 \%$ of (38-42) years, and $5 \%$ of the group age of (43 or older) respectively. The results of the age factor indicate that the young participants have great interest in social media platforms. Unlike electronic devices in which the participants login, Cellphones reached highly with percentage of $75 \%$.

As with social media platforms, Facebook was the highest percentage among other applications with $65 \%$ which indicate the tendency of most companies to create an account on Facebook for marketing. According to the results of accounts monitoring, checking several times has reached 
27\%. Consequently, representatives of the companies check their accounts on social media platforms constantly.

Table(1): Demographic Characteristics of the sample study

\begin{tabular}{|c|c|c|c|c|}
\hline Factor & Category & $\mathrm{N}$ & Percentage & Total \\
\hline \multirow[t]{2}{*}{ Gender } & Male & 49 & $34 \%$ & 132 \\
\hline & Female & 83 & $66 \%$ & \\
\hline \multirow[t]{4}{*}{ Type of device used to login } & Labtop & 25 & $19 \%$ & \\
\hline & Cellphone & 99 & $75 \%$ & \\
\hline & Tablet & 8 & $6 \%$ & \\
\hline & Others & 0 & $0 \%$ & \\
\hline \multirow[t]{6}{*}{ Age } & $18-22$ & 37 & $28 \%$ & \\
\hline & $27-23$ & 22 & $17 \%$ & \\
\hline & $28-32$ & 44 & $33 \%$ & \\
\hline & $33-37$ & 13 & $10 \%$ & \\
\hline & $38-42$ & 9 & $7 \%$ & \\
\hline & 43 or over & 7 & $5 \%$ & \\
\hline \multirow[t]{4}{*}{ Education Attainment } & High school & 49 & $37 \%$ & \\
\hline & Bachelor & 69 & $52 \%$ & \\
\hline & Master & 9 & $7 \%$ & \\
\hline & $\mathrm{PhD}$ & 5 & $4 \%$ & \\
\hline \multirow[t]{4}{*}{ Social media Platforms } & Facebook & 86 & $65 \%$ & \\
\hline & Twitter & 10 & $8 \%$ & \\
\hline & Instagram & 20 & $15 \%$ & \\
\hline & snap chat & 16 & $12 \%$ & \\
\hline \multirow[t]{8}{*}{ Accounts Monitoring } & $\begin{array}{l}\text { Several times a } \\
\text { day }\end{array}$ & 38 & $27 \%$ & \\
\hline & Every two hours & 36 & $23 \%$ & \\
\hline & $\begin{array}{l}\text { Every four } \\
\text { hours }\end{array}$ & 30 & $7 \%$ & \\
\hline & Once a day & 9 & $5 \%$ & \\
\hline & Every ten hours & 7 & $5 \%$ & \\
\hline & $\begin{array}{l}\text { Every eight } \\
\text { hours }\end{array}$ & 7 & $4 \%$ & \\
\hline & Every six hours & 5 & $27 \%$ & \\
\hline & & & $100 \%$ & \\
\hline
\end{tabular}

\subsubsection{Validity and Reliability}

Table 2 determines the validity of the conducted study items as well as the reliability of the measurement tools. The researchers used the statistical series of (SPSS V.26) and (AMOS V.25) in analyzing the stability of the questionnaire. The dimensions of persuasive language, 
argument quality, post popularity, and post attractiveness, within its (11) survey questions have driven from. [7] Persuasive language (independent variable) was measured through random selection of companies which use social media platforms as a marketing tool. The Cronbach Alpha validity of persuasive language was (0.871). On the other hand, the items' questionnaire (1-14) of e-marketing (dependent variable) through social media platforms was driven from. [12] The Cronbach Alpha validity of e-marketing was (0.833). In addition, the total validity of Cronbach Alpha for the (25) items resulted (0.907).Meanwhile, the sphericity value of the (KMAO), the adequacy of the size of the sample, was (0.884). Furthermore, the value of the explanation variance of the rotation matrix was $71.760 \%$. Moreover, the value of a latent root was (2.870). Then, the dimensional saturation coefficient resulted (0.877-0.828). Those results enabled researchers to meet the conditions of exploratory factor analysis, as shown in the results of Table (2).

Table(2): Reliability and Validity, Loading and sphericity values

\begin{tabular}{|c|c|c|c|c|c|c|}
\hline Variables & Symbol & $\begin{array}{c}\text { Numbe } \\
\text { r of } \\
\text { Items }\end{array}$ & Cronbach Alpha & $\begin{array}{l}\text { Valid } \\
\text { ity }\end{array}$ & $\begin{array}{c}\text { Factor } 1 \\
\text { before } \\
\text { Rotation }\end{array}$ & $\begin{array}{c}\text { Factor 1 } \\
\text { after } \\
\text { Rotation }\end{array}$ \\
\hline Argument Quality & $\mathrm{X} 1$ & 4 & 0.748 & 0.864 & 0.689 & 0.830 \\
\hline Post Popularity & $\mathrm{X} 2$ & 4 & 0.797 & 0.892 & 0.770 & 0.877 \\
\hline post Attractiveness & $\mathrm{X} 3$ & 3 & 0.700 & 0.836 & 0.726 & 0.852 \\
\hline $\begin{array}{l}\text { Persuasive } \\
\text { Language }\end{array}$ & $X$ & 11 & 0.871 & & & \\
\hline E-marketing & $\mathrm{Y}$ & 14 & 0.833 & 0.912 & 0.686 & 0.828 \\
\hline $\begin{array}{l}\text { Squared variance of } \\
\text { the factors }\end{array}$ & \multicolumn{6}{|c|}{2.870} \\
\hline $\begin{array}{l}\text { Total variance } \\
\text { explanation the } \\
\text { rotation matrix }\end{array}$ & \multicolumn{6}{|c|}{$71.760 \%$} \\
\hline KMO & \multicolumn{6}{|c|}{0.884} \\
\hline
\end{tabular}

Bartelet's Test $\left(\mathrm{x}^{2}\right)$

1812.780

\begin{tabular}{cc}
\hline Sig & 0.000 \\
\hline DF & 30 \\
\hline
\end{tabular}


Authors employed confirmatory factor analysis to test data of the independent variable (persuasive language). As shown in Figure (1) the (11) items that represented three dimensions of the independent variable in which it was measured. Results of confirmatory factor analysis test showed that the degree of freedom was (1.554) which is less than (5). That indicates good conformity. Meanwhile, the value of (RMSEA), (GFI), (CFI), (TLI), and (IFI) were (0.065), (0.947), (0.979), (0.956), and (0.980) respectively. Moreover, the values of items loading ranged between (0.931-0.412), which means that all of them were greater than the value of item loading (0.40) and with a level of significance less than (0.05).

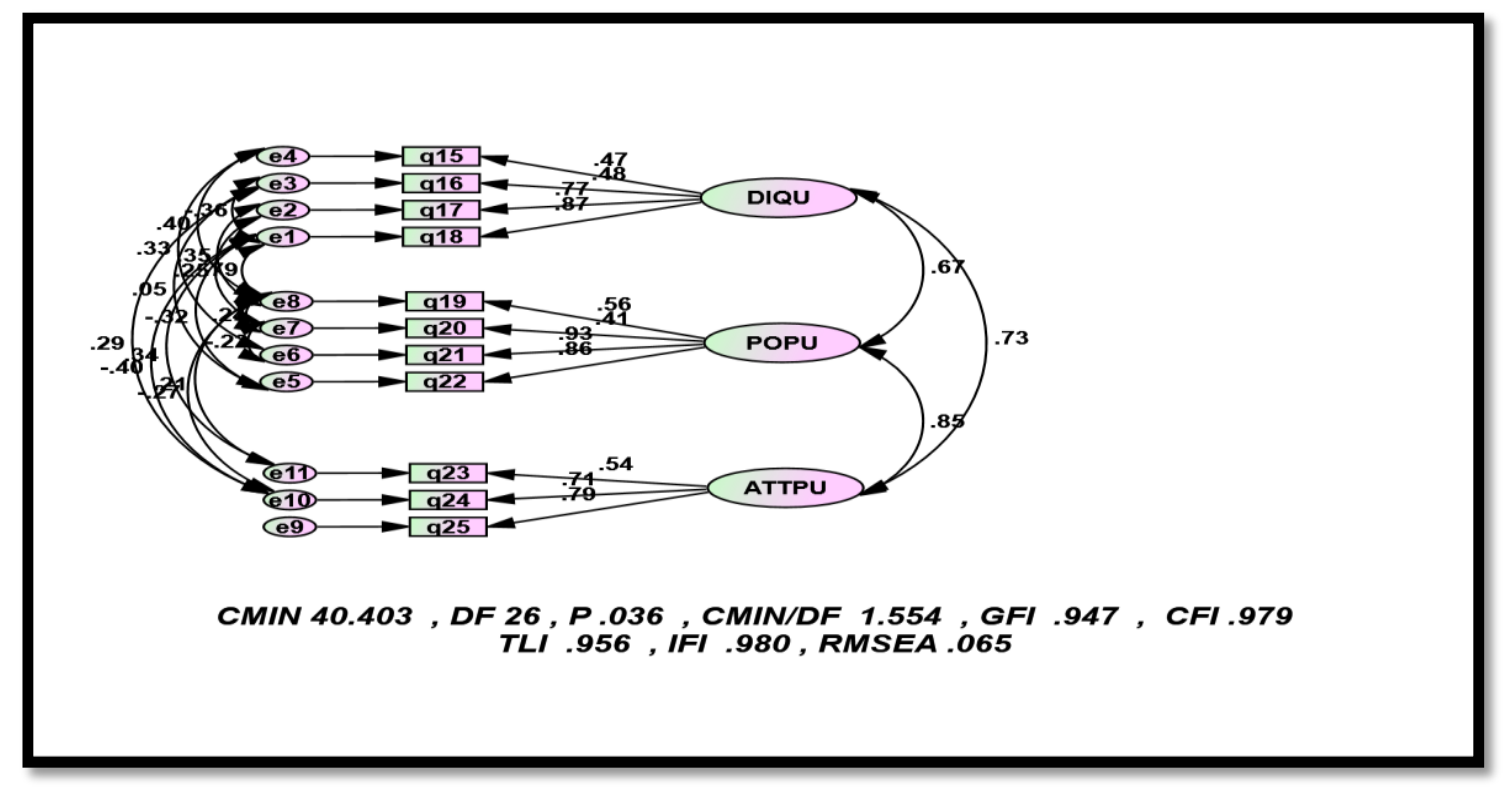

Figure(1): Factor Analysis of persuasive language data

When authors utilized confirmatory factor analysis to test the data of the dependent variable (emarketing), confirmatory factor analysis discarded (2) among (14) items, due to the fact that they did not reach the level of loading value (0.40). The results of confirmatory factor analysis as shown in Figure (2), the value of Chi Square and degree of freedom, were (88.166) and (49) correspondingly. Furthermore, the ratio of Chi Square in comparison to degree of freedom was (1.799), which is less than (5), refers to a good conformity. Additionally, (RMSEA), (GFI), (CFI), (TLI), and (IFI) were of (0.078), (0.905), (0.944), (0.924), and (0.945) respectively, and 
all of those tests were under a significant of (0.05). The loading values of items ranged between (0.853-0.404) and all of them were greater than the loading value (0.40).

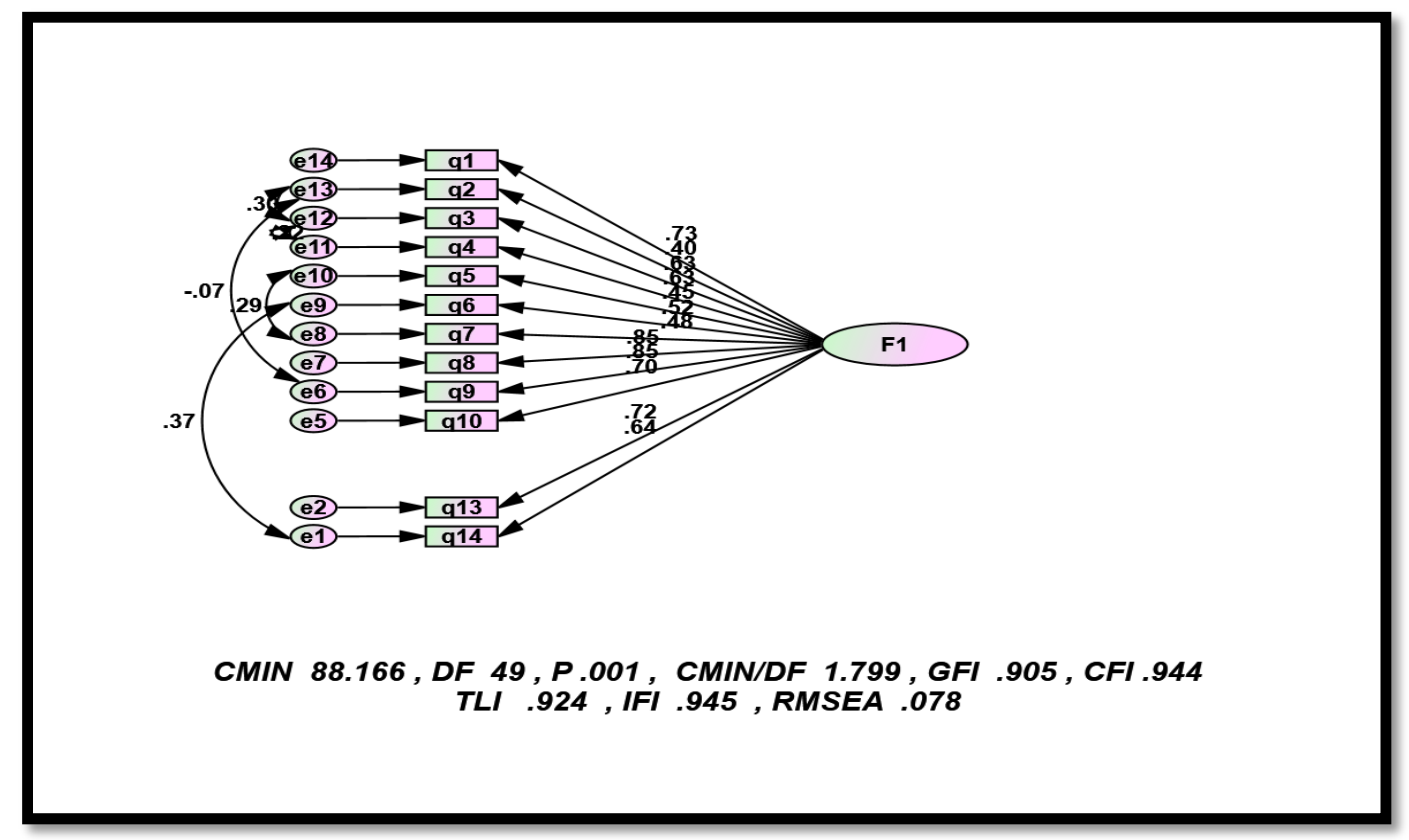

Figure(2): Factor Analysis of E-marketing data

\subsection{Major Findings:}

Table 3 shows that persuasive language (independent variable) obtained its mean with (3.82), Materiality 76.4\%, a standard deviation (0.647), and a Coefficient of variation $17 \%$. Argument quality was the highest interest dimension from the perspective of companies' representatives. It reached with (4.01) mean, Materiality $80.2 \%$, Coefficient of variation $16 \%$, and a standard deviation (0.644). This illustrates that customers will be willing to prefer buying their goods and taking advantages of their services when companies deal professionally and logically with argument of customer's opinions and comments. Therefore, convincing style through objective persuasion and high credibility are solid power that of which companies can use to prosper their businesses. Moreover, e-marketing (dependent variable) gained a mean of (3.74), materiality $74.8 \%$, a standard deviation (0.558), Coefficient of variation $15 \%$ 
Consequently, those results show strong agreement of the study sample that various companies ought to participate in marketing through social media platforms especially in buying, selling, and negotiating electronically.

Table(3): Descriptive Analysis of Variables of the study $(n=132)$

\begin{tabular}{lcccc}
\hline Variables & Mean & $\begin{array}{l}\text { Standard } \\
\text { Deviation }\end{array}$ & $\begin{array}{l}\text { Materiali } \\
\text { ty }\end{array}$ & $\begin{array}{l}\text { Coefficie } \\
\text { nt of } \\
\text { variation }\end{array}$ \\
\hline Persuasive Language & 3.82 & 0.647 & $76.4 \%$ & $17 \%$ \\
Argument Quality & 4.01 & 0.644 & $80.2 \%$ & $16 \%$ \\
Post Popularity & 3.69 & 0.807 & $73.8 \%$ & $22 \%$ \\
post Attractiveness & 3.78 & 0.771 & $75.6 \%$ & $20 \%$ \\
E-marketing & 3.74 & 0.558 & 74.8 & $15 \%$ \\
\hline
\end{tabular}

\subsubsection{Hypotheses Tests:}

$H^{0}$ : persuasive language positively affects e-marketing through social media platforms.

$H^{l}$ : Argument quality of persuasive language positively affects e-marketing through social media platforms.

$\mathrm{H}^{2}$ : Post popularity of persuasive language positively affects e-marketing through social media platforms.

H3: Post Attractiveness of persuasive language positively affects e-marketing through social media platforms.

Table (4) shows that the level of significance of the influence of the main independent variable (persuasive language) in e-marketing reached (0.000), which is less than the level of significance (0.05). Moreover, the calculated value of (F) was (120.687), greater than its tabular value (3.841), whereas the value of the calculated T-test for marginal propensity significance 
with (10.985), greater than its tabular value (1.96) at the level of significance (0.05). Hence, we accept the main hypothesis (persuasive language positively affects e-marketing through social media platforms). Persuasive language underscores its influence on e-marketing changes with $48.1 \%$ among its overall variables.

Regarding the level of significance of the interpretation of argument quality of the changes in electronic marketing, it resulted (0.000), greater than the level of significance (0.05). Meanwhile the calculated value of (F) (68.158), less than its tabular value (3.841). As With the value of the T-test, it is calculated in marginal propensity significance with (8.256), greater than the tabular value (1.96) at the level of significance (0.05). It has been found that the main sub hypothesis is accepted (Argument quality of persuasive language positively affects e-marketing through social media platforms).

Concerning the overall impact on the changes in e-marketing, quality of the argument has $34.4 \%$ impact as opposed to $65.6 \%$ of other remaining variables. Furthermore, marginal propensity of argument quality was (0.507). Meaning companies that pay more attention to the quality of argument with costumers through social media platforms, e-marketing will be dramatically increased with $50.7 \%$.

Similarly, post popularity affects the alteration of e-marketing through social media platforms with percentage of $40.2 \%$ in comparison with $59.8 \%$ of other attributed remaining variables. In addition, marginal propensity of post popularity was (0.438), which illustrates that adding more features to post popularity would increase the performance level of e-marketing with $43.8 \%$. The calculated value of $(\mathrm{T})$ reached $(9,345)$ which proves significance, while the calculated value of (F) for variance model was (87.330) with a significant level (0.000). In other words, it is less than the significant level (0.05). Thus, the results are in good agreement with the second 
alternative hypothesis (Post popularity of persuasive language positively affects e-marketing through social media platforms.

Obviously the level of significance of post attractiveness reached $(0,000)$ which is less than the level of significance (0.05). In addition to that, the calculated value of $(F)$ was (71.102) which is greater than its tabular value (3.841). The calculated value of T-test for marginal propensity was (8.432) which is greater than its tabular value (1.96) at the level of significance (0.05). Those findings strongly support the third alternative hypothesis (Post Attractiveness of persuasive language positively affects e-marketing through social media platforms).

Post attractiveness showed its ability to affect e-marketing by $35.4 \%$ in comparison with the other remaining with percentage of $64.6 \%$. The marginal propensity of post attractiveness valued with $43 \%$ with regards to e-marketing.

Table(4): Impact of Persuasive language dimensions on E-marketing $(n=132)$

\begin{tabular}{|l|c|c|c|c|c|c|c|}
\hline $\begin{array}{l}\text { Independent } \\
\text { Variables }\end{array}$ & \multicolumn{7}{|c|}{ Dependent Variable E-marketing } \\
\hline & $\mathrm{T}$ & $\mathrm{B}$ & $\mathrm{A}$ & $\mathrm{F}$ & $\mathrm{P}$ & $\mathrm{R}^{2}$ & $\mathrm{R}$ \\
\hline $\begin{array}{l}\text { Argument } \\
\text { Quality }\end{array}$ & 8.256 & .507 & 1.711 & 68.158 & .000 & .344 & .586 \\
\hline Post Popularity & 9.345 & .438 & 2.129 & 87.330 & .000 & .402 & .634 \\
\hline $\begin{array}{l}\text { post } \\
\text { Attractiveness }\end{array}$ & 8.432 & .430 & 2.118 & 71.102 & .000 & .354 & .595 \\
\hline E-marketing & 10.985 & .598 & 1.459 & 120.667 & .000 & .481 & .694 \\
\hline
\end{tabular}

In order to test the research model through overall impact of persuasive language dimensions, the researchers employed the multiple regression. As shown in Figure (3) and Table (4), the companies who utilize social media platforms for distributing its goods and services, tend to employ post attractiveness with (0.321), level of significance (0.000), and value of the critical ratio (3.404). Correspondingly argument quality reached an impact values of (0.248), level of significance (0.003), and critical rate value (2.923). Next, the ability of companies to empower 
its post popularity relies on increasing the impact of proper usage of social media platforms on emarketing with (0.225), a level of Significance (0.013) with critical percentage value (2.489). In comparison with the tabular value of critical ratio (1.96) at the level of significance (0.05), the three dimensions are synergistic and mutually influential which lead to influence e-marketing with percentage of $79.4 \%$, a high synergistic effect.

Table(5): Multiple regression of Persuasive language dimensions on E-marketing $\quad(n=132)$

\begin{tabular}{|c|c|c|c|c|c|c|c|}
\hline $\begin{array}{l}\text { Independent } \\
\text { Variables }\end{array}$ & $\begin{array}{l}\text { Impact } \\
\text { Directio } \\
\mathrm{n}\end{array}$ & $\begin{array}{l}\text { Depende } \\
n t \\
\text { Variable }\end{array}$ & $\begin{array}{l}\text { impact } \\
\text { parameter }\end{array}$ & $\begin{array}{l}\text { St. } \\
\text { error }\end{array}$ & Materiality & $\begin{array}{l}\text { significan } \\
\text { ce level }\end{array}$ & $\begin{array}{l}\text { significanc } \\
\mathrm{e}\end{array}$ \\
\hline $\begin{array}{l}\text { Argument } \\
\text { Quality }\end{array}$ & $----\rightarrow$ & \multirow{3}{*}{$\begin{array}{c}E- \\
\text { marketin } \\
g\end{array}$} & 0.248 & .073 & 2.923 & 0.003 & $\begin{array}{c}\text { Significan } \\
\text { ce }\end{array}$ \\
\hline Post Popularity & $----\rightarrow$ & & 0.225 & .065 & 2.489 & 0.013 & $\begin{array}{c}\text { Significan } \\
\text { ce }\end{array}$ \\
\hline $\begin{array}{l}\text { post } \\
\text { Attractiveness }\end{array}$ & $----\rightarrow$ & & 0.321 & .065 & 3.404 & 0.000 & $\begin{array}{c}\text { Significan } \\
\text { ce }\end{array}$ \\
\hline
\end{tabular}

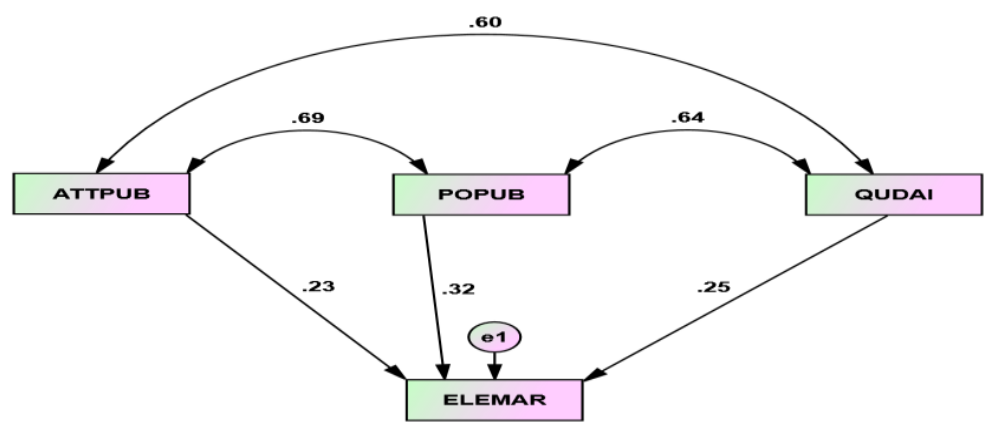

Figure(3): Impact of multiple dimensions of persuasive language dimensions on E-marketing.

\section{Conclusion}

Persuasive language promotes both customers' loyalty and reliability. Representatives of the companies should be responsible for keeping customer's credibility by responding to them as soon as possible and also encouraging them to expose their 
problems through social media platforms. If companies ensure customers by providing an active link to general information such as firm's mission, operation, and goal, it will be easy for customers to reach diverse information immediately. Interacting with customers through social media platforms would probably add new ideas to improve a company product and those ideas could be a good conception if taken seriously .

Social media platforms can really provide many features to push small business to an active marketplace. American Express would help businesses with insufficient budgets to reach as many people as possible. Advertising on social media platforms can improve businesses efficiently and effectively by connecting them with numerous customers. Small businesses that want to establish a new business in the marketplace have better idea to start with social media platforms, instead of wasting money on many advertisements that may not pay off.

Persuasive language helps various businesses and enterprises to receive feedback from customers about how to address problems and obstacles properly. Companies, that are becoming successful through doing online marketing, should encourage other organizations to enter the online market to participate and gain profitable benefits or profits at the same time.

Therefore, public sector institutions and companies must take into consideration the private sector's experience in how to deal with customers or beneficiaries and gain profitable benefits and returns at the same time. This can be a first step for future studies. 


\section{List of Resources and References:}

[1] Bourne, S, How Twitter can help your business grow, Photo District News, (2009) 18-22.

[2] Burton, S., \& Soboleva, A, Interactive or reactive? Marketing with twitter, The Journal of Consumer Marketing, 28(7) (2011) 491-499.

[3] Constantinides, Efthymios, CSIM: Foundations of Social Media Marketing, Procedia - Social and Behavioral Sciences 148 (2014) 40-57.

[4] Fridolf, Malin, Arnautovic. Alem, Social Media Marketing, Master Thesis in International Business, Department of Economics and Informatics- University WestTrollhättan, (2011) 27-28

[5] Guffey, M. E., Loewy, D, Essentials of Business Communication, $9^{\text {th }}$ edition, Mason, OH: Cengage Learning. USA. (2009).

[6] Horn, L., Twitter Rolling Out Self-Serve Ads to Small Businesses, PC Magazine, (2012) 111.

[7] Keskin, H., A.E. Akgün, H. Ayar, T. Etlioglu, Persuasive messages and emotional responses in social media marketing. Journal of Management, Marketing and Logistics (JMML), 4(3) (2017) 202-208.

[8] Miller, C. Cain, Marketing small businesses with Twitter, The New York Times Company, (2009) 1-3.

[9] Paquette,Holl, "Social Media as a Marketing Tool: A Literature Review", Major Papers by Master of Science Students, University of Rhode Island, 20 (2013) 1-26.

[10] Pattison, K., Reach customers in 140 characters, all of them free, The New York Times Company, (2010) 1-4.

[11] Rosen, A., The E-commerce Question and Answer Book: A Survival Guide for BusinessManagers, American Management Association, USA.(2002).

[12] Salih, Faeza Adnan, Using social media as an interactive tool for learning and teaching purposes, Alaustath Journal for Human and Social sciences -Iraq (Special Issue of the $7^{\text {th }}$ scientific conference), 1 (7) (2019) 13-26.

[13] Thoring, A., Corporate Tweeting: Analysing the Use of Twitter as a Marketing Tool, UK Trade Publishers, 27(2) (2011) 141-142

[14] Weber, S., Twitter marketing, Stephen W. Weber, USA. (2009). 